\title{
Klauzula sumienia w szkole
}

\section{THE CONSCIENCE CLAUSE AT SCHOOL}

Discussion of the conscience clause at schools concerns the possibility to refuse the teacher's actions incompatible with his conscience. This possibility, though questioned by many as unlawful, results from Polish legislation and international law. It is a consequence of freedom of conscience guaranteed by the Constitution of the Republic of Poland and a number of international and national legal acts. There are many situations in which reveals the conflict between the duty of performing a given program or command of educational authorities and their own convictions. They concern mainly the same vision of the school and its functions, school programs and the underlying concept of the human being and interpersonal relationships at the level of professional work of the teacher. In all these situations, the teacher should be a person of conscience, i.e. to follow his voice, which sometimes means opposition to the content of curricula and textbooks, orders of superiors or the prevailing customs.

Key words: conscience, the conscience clause, school, professional ethics.

Kiedy z inicjatywy dr Wandy Półtawskiej niemal 4 tys. lekarzy, pielęgniarek oraz studentów medycyny podpisało tzw. Deklarację wiary $^{1}$, zawierającą stwierdzenie prawa do sprzeciwu wobec działań

Pełny tytuł: Deklaracja wiary lekarzy katolickich i studentów medycyny $w$ przedmiocie ptciowości i płodności ludzkiej. Dokument został opublikowany 5 marca 2014 roku. Treść Deklaracji wyryta na dwóch kamiennych tablicach została złożona na Jasnej Górze jako dar wotywny za kanonizację Jana Pawła 
niezgodnych z sumieniem², niemal od razu pojawiło się pytanie: „a co z wrażliwością innych grup zawodowych?" i zrodził się pomysł, aby klauzulę sumienia rozszerzyć również na przedstawicieli innych profesji, w tym nauczycieli. O ile żądanie prawa, które pozwala na odmowę pewnych czynności w ramach zawodów lekarskich wywołało burzliwą dyskusję, to sama opinia, że można klauzulę sumienia stosować także w szkolnictwie spowodowała prawdziwą ministerialną panikę. Oto kolejna grupa zawodowa, znacząca nie tylko z racji liczebności, ale i opiniotwórczego wpływu, okazuje brak posłuszeństwa i wymyka się spod kontroli władzy.

Rozpoczęła się dyskredytacja klauzuli w mediach. Pojawiło się szereg ironicznych tekstów ${ }^{3}$, prześmiewczych memów, wypowiedzi rzekomo oburzonych rodziców, a nawet wyniki badań socjologicznych wskazujących na poczucie zagrożenia społeczeństwa ze strony rzekomo pełzającego klerykalizmu, państwa wyznaniowego oraz religijnego (czytaj: katolickiego) fundamentalizmu ${ }^{4}$. Powołano „dyżurne” autorytety, także ze środowiska kościelnego, by wykazać jej szkodliwość. Wypowiedzi tych tzw. ekspertów ujawniły nie tylko ich totalną ignorancję w kwestiach wiary i moralności, zwłaszcza chrześcijańskiej (bo ta stała się głównym przedmiotem ataków), ale także w zakresie podstawowej terminologii. I tak np. pojawiały się karkołomne konstrukcje typu: „Kościół uznaje seks za zło, dlatego klauzula sumienia nie pozwoli o nim mówić”; „Kościół wyznaje kreacjonizm, więc nie pozwoli, by w ramach biologii zajmować się ewolucjonizmem" itp. Na czym więc polega istota klauzuli sumienia i jakie są „za” i „przeciw” jej stosowaniu w szkole?

II podczas 90. Pielgrzymki Służby Zdrowia 25 maja 2014 r. Pełny tekst dostępny pod adresem http://www.deklaracja-wiary.pl/img/dw-tresc.pdf

2 „Stwierdzam, że podstawą godności i wolności lekarza katolika jest wyłącznie jego sumienie oświecone Duchem Świętym i nauką Kościoła i ma on prawo działania zgodnie ze swoim sumieniem i etyką lekarską, która uwzględnia prawo sprzeciwu wobec działań niezgodnych z sumieniem”, nr 4.

3 Na przykład „Piekarz nie wypiecze chleba, bo część mąki pochodzi z zagranicznego zboża, a to kłóci się z jego patriotyczną postawą. Albo strażak odmówi wyjazdu do pożaru, bo ogień objął dom publiczny, który w jego opinii nie powinien w ogóle funkcjonować”. Cyt. za: http://natemat.pl/104381,internauci-smieja-sie-z-klauzuli-sumienia-strazak-policjant-nauczyciel (30.01.2015 r.).

4 Por. http://www.se.pl/wydarzenia/kraj/polacy-przeciw-klauzuli-sumienia_407446. html (30.01.2015 r.). 


\section{„Za” i „przeciw” klauzuli sumienia nauczycieli}

Przeciwnicy klauzuli sumienia objawili swoje lęki przed ideologizacją szkoły. Nauczycieli - mówią - nie zatrudnia się w celu ewangelizacji uczniów, gdzie indziej jest na to miejsce $\left(\mathrm{K}\right.$. Hall) ${ }^{5}$. Podpisywanie przez nauczycieli deklaracji wiary mogłoby - według nich - oznaczać, że uczyliby tylko tego, co jest zgodne z nauką Kościoła (W. Nowicka) ${ }^{6}$. Obawy przeciwników dotyczą także wyrażającego się rzekomo poprzez stosowanie klauzuli prymatu religii przed nauką i wiary przed rozumem. Dlatego postulują rozdzielenie sfery prywatnej i publicznej (rzekomo jako osoby prywatne nauczyciele mogą robić wszystko; to jest ich prywatna sprawa; w momencie jednak, kiedy pełnią określone funkcje, ich przekonania nie powinny mieć nic do rzeczy).

„Szkoła powinna być neutralna światopoglądowo, a nauczyciel powinien w swojej pracy tę neutralność zachować, inaczej łamie prawo" - grzmiała Joanna Kluzik-Rostkowska. Minister pogroziła nawet nauczycielom: „Jeśli podpiszą deklarację złamią prawo i powinni liczyć się z reakcją dyrektora szkoły, kuratora i wojewody"7. W jednym z wywiadów p. Minister dopowiada: „Nauczyciel w szkole publicznej ma obowiązek uczyć zgodnie z prawem. Jest funkcjonariuszem publicznym i ma się kierować podstawą programową. Jeżeli nie, to niech zmieni zawód"8. Minister edukacji poinstruowała jednocześnie, że ,[...] każdy rodzic, który poczuje się zaniepokojony sytuacją, ma prawo zwrócić się do wojewody w tej sprawie. Wojewoda uruchomi wówczas postępowanie dyscyplinarne wobec takiego nauczyciela”.

Tak ostre stanowisko Minister argumentuje, powołując się na Konstytucję i art. 6 Karty Nauczyciela. Problem jednak (dodajmy: problem p. Minister) polega na tym, że ani w Konstytucji, ani w Karcie Nauczyciela zwrot „neutralność światopoglądowa” nie występuje. Przeciwnie, przywołane akty prawne mówią o poszanowaniu „wolności sumienia i szacunku dla każdego człowieka”. Tak np. art. 6. Karty Nauczyciela głosi: „nauczyciel obowiązany jest [...] kształcić i wychowywać młodzież w umiłowaniu Ojczyzny, w poszanowaniu Konstytucji Rzeczypospolitej

$5 \quad$ http://www.polskieradio.pl/5/3/Artykul/1190178,Deklaracja-wiary-nauczycieliHall-nie-zatrudnia-sie-ich-w-celu-ewangelizacji-uczniow (30.01.2015 r.). lach-Nowicka-nauczyciel-nie-moze-cenzurowac-wiedzy (30.01.2015 r.).

7 http://www.polskieradio.pl/5/3/Artykul/1188918,Nauczyciele-tez-beda-podpisywac-deklaracje-wiary-Minister-szkola-publiczna-powinna-byc-neutralnaswiatopogladowo (30.01.2015 r.). 
Polskiej, w atmosferze wolności sumienia (podkreśl. T. Z.) i szacunku dla każdego człowieka oraz dbać o kształtowanie u uczniów postaw moralnych (podkr. T. Z.) i obywatelskich [...]" .

Wolność sumienia gwarantują obywatelom także inne regulacje prawne. Chodzi tu o artykuł $30^{9}, 31^{10}$, a zwłaszcza 53 Konstytucji RP, który zapewnia każdemu obywatelowi wolność sumienia i wyznawanej religii ${ }^{11}$. Także art. 9 Europejskiej Konwencji Praw Człowieka z 1950 roku gwarantuje wolność myśli, sumienia i wyznania. Natomiast Karta Praw Podstawowych Unii Europejskiej z 2000 roku wprost przyznaje prawo do odmowy wykonywania czynności niezgodnych z własnym sumieniem (art. 10) ${ }^{12}$.

Instytucja klauzuli sumienia nie łamie więc prawa, więcej - wynika z prawa polskiego i międzynarodowego. Znajduje ona swoje zakorzenienie w wolności sumienia i religii gwarantowanej w Konstytucji oraz szeregu umów międzynarodowych dotyczących praw człowieka. Klauzula sumienia jest instrumentem realizacji wolności sumienia. Stanowi ona, że państwo lub inna instytucja społeczna nie może zmuszać nikogo do działania wbrew jego sumieniu. Wolność sumienia i religii nie oznacza bowiem wyłącznie prawa do swobodnego wyboru światopoglądu czy też prawa do uzewnętrzniania religii przez akty kultu. Oznacza ona także swobodę dokonywania własnych ocen moralnych, jak również swobodę postępowania zgodnie z własnym sumieniem wraz z wolnością od przymusu działania wbrew temu sumieniu ${ }^{13}$.

W art. 30. mówi się o przyrodzonej godności człowieka - źródle jego wolności i praw. Godność nie jest tu zdefiniowana, ale jest podstawą stanowienia całego ustawodawstwa w europejskiej kulturze prawnej.

Artykuł 31 w ust. 3 gwarantuje prawa człowieka w sytuacjach konfliktowych.

Artykuł 53. a) „Każdemu zapewnia się wolność sumienia i religii. b) Wolność religii obejmuje wolność wyznawania lub przyjmowania religii według własnego wyboru oraz uzewnętrzniania indywidualnie lub z innymi, publicznie lub prywatnie, swojej religii przez uprawianie kultu, modlitwę, uczestniczenie w obrzędach, praktykowanie i nauczanie. Wolność religii obejmuje także posiadanie świątyń i innych miejsc kultu w zależności od potrzeb ludzi wierzących oraz prawo osób do korzystania z pomocy religijnej tam, gdzie się znajdują".

Artykuł 10. 1. „Każdy ma prawo do wolności myśli, sumienia i religii. Prawo to obejmuje wolność zmiany religii lub przekonań oraz wolność uzewnętrzniania, indywidualnie lub wspólnie z innymi, publicznie lub prywatnie, swej religii lub przekonań poprzez uprawianie kultu, nauczanie, praktykowanieiuczestniczenie w obrzędach. 2. Uznaje się prawo do odmowy działania sprzecznego z własnym sumieniem, zgodnie z ustawami krajowymi regulującymi korzystanie z tego prawa".

13 Por. P. Stanisz, Prawo do odmowy dziatania sprzecznego z sumieniem, www. przemyska.pl/plik/22141/ (30.01.2015 r.). 
Według zgodnych opinii prawników takie wnioski są wyprowadzane na gruncie prawnym z przytoczonych wyżej aktów, a nie wyłącznie na gruncie teologii katolickiej. Owszem, w świetle ustawodawstwa prawo do sprzeciwu sumienia może być ograniczone (mówi o tym cytowany art. 10 Karty Praw Podstawowych, który odsyła do ustaw krajowych regulujących korzystanie z tego prawa). Jednak to nie sprzeciw sumienia jest wyjątkiem. Wyjątkiem jest jego ograniczanie. A więc uznanie, że ktoś ma prawo do sprzeciwu sumienia nie jest żadnym przywilejem; jest to generalna reguła, wyprowadzana z zasady wolności myśli, sumienia i wyznania. To jej ograniczenie jest wyjątkiem i powinno być szczegółowo uzasadnione (np. ze względu na ochronę bezpieczeństwa państwa, porządku publicznego, zdrowia, moralności, praw i wolności innych osób, a nadto nie może naruszać samej istoty wolności sumienia i religii) ${ }^{14}$.

Klauzula sumienia, choć występuje w prawie państwowym, nie pochodzi z nadania państwa. Jest ona bardziej pierwotna od jakiegokolwiek prawa państwowego. Wynika ona z ludzkiej godności, a nie tylko z tego, że jakieś państwo czy władza udzieli jej obywatelowi. Człowiek jest wolny! W ramach tej wolności mieści się też wolność sumienia. Nawet jeśli w uzasadnionych sytuacjach prawo państwowe ją ogranicza, to jest to sytuacja wyjątkowa. Dlatego to nie nauczyciele mają uzasadniać swoje prawo do sprzeciwu sumienia, ale Minister ma wytłumaczyć dlaczego chce ograniczać to prawo.

W tym kontekście trzeba spojrzeć na uzasadnienie ograniczenia prawa do sprzeciwu sumienia nauczyciela, jakim jest przywołana przez Minister „neutralność światopoglądowa szkoły”. Jak już wspomniano, polskie ustawodawstwo nie zawiera takiego uzasadnienia. Ponadto, używając terminu „,neutralność światopoglądowa”, p. Minister nie precyzuje, o który model neutralności jej chodzi. Należy bowiem pamiętać, że istnieją przynajmniej trzy takie modele: amerykański model separacji czystej, system separacji wrogiej w wersji francuskiej (skrajnie liberalny) oraz system separacji skoordynowanej (model niemiecki).

W błędzie są ci, którzy twierdzą, że Polska jest krajem laickim. Powoływanie się na Konstytucję RP w celu szeroko pojętego usuwania religii z życia społecznego i publicznego (w tym negowania prawa do sprzeciwu sumienia) jest nieuprawnione. Nieuprawnionym jest też odwoływanie się do tzw. normalności europejskiej, bo taka nie istnieje. W UE egzystują obok siebie państwa, które wybrały model „neutralny” i model „laicki”. Jak się okazuje model laicki jest w zdecydowanej mniejszości. Obecnie nawet jego radykalne stanowisko wobec religii 
ulega złagodzeniu ${ }^{15}$. Polska jednak nie jest krajem laickim, ale państwem o modelu separacji skoordynowanej.

To, co p. Minister nazywa neutralnością jest raczej bezstronnością światopoglądową. Nie można jednak tych dwóch rzeczy utożsamiać. Termin „bezstronność” rzeczywiście występuje w Konstytucji (art. 25). Jednakże kategoria ta dotyczy nie tyle nauczycieli, ile władzy publicznej, w tym ministra oraz organów prowadzących szkołę. To przede wszystkim te organy mają być bezstronne światopoglądowo, tzn. bezstronne wobec światopoglądu nauczycieli, rodziców i dzieci ${ }^{16}$. Jak widać, kontestacja klauzuli sumienia w szkole ma bardzo słabe podstawy prawne i etyczne. Opowiadając się za możliwością jej stosowania warto wskazać na główne obszary pracy zawodowej nauczyciela, gdzie odmowa pewnych działań motywowana ich niezgodnością z sumieniem jest jak najbardziej uzasadniona.

\section{Obszary sprzeciwu sumienia nauczyciela}

Sumienie bywa terenem konfliktów i wątpliwości moralnych w odniesieniu do wielu dziedzin ludzkiego życia. Jedną z takich dziedzin, gdzie - zwłaszcza w ostatnim czasie - rodzi się wiele dylematów i konfliktów sumienia, jest praca i życie zawodowe. Dziedziny te stały się wręcz miejscem ,próby sumień”. Jest ogromnie dużo wyzwań dla sumienia człowieka, jakie płyną z życia zawodowego. Nie sposób ich wszystkich przedstawić. Zresztą każdy rodzaj wykonywanej pracy i każdy zawód niesie wyzwania specyficzne. Jednak szczególne „próby” dla sumienia niosą te zawody, w których „przedmiotem” pracy jest drugi człowiek. Do takich zawodów obok medycyny należą także te związane z kształceniem i wychowaniem.

Lekarze przeżywają konflikt sumienia, gdy prawo nakazuje im dokonanie aborcji bądź wskazanie innego lekarza, który to zrobi; farmaceuci w przypadku sprzedaży środków wczesnoporonnych; a co takiego jest w polskiej szkole, że nauczyciele musieliby się bronić klauzulą sumienia? Przeciwnicy powiedzą: nic. Wydaje się jednak, że sytuacji takich jest sporo, choć mają one inny charakter niż np. w zawodach medycznych. Tam bowiem to Ustawa nakazuje wprost pewne działania.

15 Prezydent Sarkozy zaczął swego czasu używać terminu „laickość otwarta” bądź „laickość pozytywna”, do czego - jak się wydaje - z akceptacją odniósł się Benedykt XVI podczas swojej wizyty we Francji w 2008 roku.

16 Konstytucja RP art. 25: „Kościoły i inne związki wyznaniowe są równouprawnione. 2) Władze publiczne w Rzeczypospolitej Polskiej zachowują bezstronność w sprawach przekonań religijnych, światopoglądowych i filozoficznych, zapewniając swobodę ich wyrażania w życiu publicznym”. 
W przypadku nauczycieli chodzi nie tyle o konkretne przepisy prawne, bo być może sama Podstawa programowa nie nakazuje niczego złego. Chodzi raczej o szczegółową treść programów i podręczników, polecenia przełożonych, a niekiedy o panujące zwyczaje. To one stały się miejscem, gdzie wyśmiewa się wiarę, a nawet ogólnoludzką etykę; gdzie w negatywnym świetle przedstawia się Ojczyznę, jej dzieje, historię, kulturę, ludność. Do programów wprowadza się idee genderyzmu, a za to usuwa się terminologię związaną z religią, zwłaszcza z chrześcijaństwem. I okazuje się to zgodne z Podstawa programowa. Natomiast, kiedy nauczyciel broni Kościoła i klasycznej etyki, może się to okazać z tą Podstawa niezgodne.

Warto zwrócić uwagę na kilka typowych sytuacji, w których ujawnia się konflikt między powinnością realizacji ustalonego programu czy poleceń władz oświatowych a własnymi przekonaniami. Pierwsza grupa takich sytuacji związana jest z koniecznością odpowiedzi na pytanie: jakim wartościom ma służyć praca nauczyciela i w czym ostatecznie należy upatrywać wartość tej pracy? To pytanie rodzi się wszędzie tam, gdzie pracę zawodową nauczyciela stara się wprzęgnąć w służbę jedynie słusznej ideologii i jedynie dopuszczalnego światopoglądu, tzw. światopoglądu naukowego, a szkołę próbuje się sprowadzić do roli narzędzia planowej ateizacji. Tymczasem zadaniem szkoły jest integralne wychowanie człowieka i to w ścisłej współpracy z rodzicami wedle zasady pomocniczości. Szkoła zatem pełni funkcję formacyjną i w wypełnianiu tej funkcji nie posiada absolutnej autonomii. Nie jest ona tylko miejscem kształcenia, ale środowiskiem wzrostu fizycznego, intelektualnego, społecznego, moralnego, estetycznego, a także religijnego, spełniając rolę pomocniczą wobec rodziców. Sprzeciw sumienia winna zatem budzić najpierw każda próba zastępowania rodziców w ich funkcji wychowawczej, zwłaszcza gdy takie próby podejmują osoby niekompetentne ${ }^{17}$. Każdy więc program nauczania stworzony bez rodziców czy tym bardziej wbrew rodzicom zasługuje na zdecydowany sprzeciw ${ }^{18}$. Klauzula sumienia nauczyciela będzie w tym przypadku formą zabezpieczenia dzieci przez ideologizacją.

17 W 2015 roku do pracy nad e-podręcznikiem powołano „ekspertów” z zakresu kolorowej prasy kobiecej.

18 Takie ograniczenia wpływu rodziców zawierają dyskutowane obecnie w sejmowej komisji poprawki Ustawy. W wypadku szkoły publicznej istnieje obowiązek, by program wychowawczy uzgodnić z rodzicami, „czyli wychowanie prowadzić tak, jak oni tego oczekują". Natomiast obecnie MEN chce poszerzyć m.in. kompetencje kuratorów oraz ograniczyć wpływ samorządów lokalnych na działanie prowadzonych przez nie szkół oraz rodziców na wychowanie ich dzieci. Istnieje 
U podstaw wychowania stoi zawsze jakaś wizja człowieka. Wychowanie, w sposób jawny bądź ukryty, zawsze styka się ze światopoglądem; nie jest nigdy moralnie obojętne, nawet gdy usiłuje się głosić jego „neutralność” etyczną i religijną. Także liberalny neutralizm nie jest neutralny, ale narzuca z góry swoją wizję moralności. Czyni to podstępnie, ponieważ krytykując inne koncepcje moralności, ukrywa swoje założenia antropologiczne i etyczne. Z jednej bowiem strony, zwolennicy neutralności, występując w imieniu uniwersalistycznych zasad współżycia, twierdzą, iż chronią pluralizm i nie chcą żadnej wspólnocie narzucać obcego im punktu widzenia. Z drugiej, promują oni własny punkt widzenia, a stopień ucywilizowania społeczeństwa oceniają według stopnia jego akceptacji.

Nie jest zatem obojętne jaką wizję człowieka, jakie modele życia, jaką hierarchię wartości, jaką wizję wolności, jaki stosunek do dziedzictwa kultury wytworzonej przez przeszłe pokolenia proponuje się dzieciom i młodzieży. Sprzeciw winny budzić stojące u podstaw programów szkolnych fragmentaryczne bądź wprost zafałszowane antropologie. Dlatego klauzulą sumienia powinny być objęte takie sytuacje, gdy program szkolny bądź przełożony nakazuje uczyć o człowieku jako absolutnym indywiduum bądź - przeciwnie - jako kolektywnej masie, o płci jako rzeczywistości jedynie społeczno-kulturowej, o wolności jako niczym nieskrępowanej możliwości wyboru, a zwłaszcza nieskrępowanej miłością, bezinteresownością, odpowiedzialnością; kiedy wychowanie seksualne miałoby być instruktażem korzystania ze środków antykoncepcyjnych.

Sprzeciw winno budzić nie tylko sprowadzenie funkcji nauczycielskiej wyłącznie do przekazywania jakiegoś zespołu wiadomości, ale także niektóre ujęcia samej nauki oraz sposoby przekazywania wiedzy. Nauczyciel musi działać w granicach kompetencji nauki. Musi uczciwie i rzetelnie przekazywać wiedzę zgodną z prawdą. Nie może przekazywać treści niesprawdzonych, hipotetycznych czy interpretacji jednostronnych jako pewników. Może więc i powinien odmówić przekazywania pseudo-prawd i pseudo-wiedzy (co ma np. wspólnego z wiedzą i nauką andrzejkowe wróżbiarstwo albo obchody Halloween?). Poza tym nauczyciel powinien ujawniać i prostować wszelkie błędne informacje naukowe podawane do publicznej wiadomości. Zapoznając się z najnowszymi osiągnięciami w nauce, powinien odnosić się do nich z umiarem, krytycyzmem oraz odpowiedzialnością, wprowadzając do swojej pracy tylko te innowacje, które służą realizacji celu, jakim jest 
pozytywny rozwój moralny, duchowy, intelektualny i fizyczny ucznia oraz studenta. Może zatem i powinien odmówić „eksperymentowania” treściami oraz metodami, formami i środkami kształcenia, które uznaje za sprzeczne z jego sumieniem (np. uczenie równouprawnienia płci przez odgrywanie tzw. niestereotypowych ról).

Kolejna grupa sytuacji konfliktowych obejmuje te wyzwania dla sumienia nauczyciela, które rodzą się na płaszczyźnie relacji międzyosobowych. Chodzi tu głównie o konflikt między dyscypliną i lojalnością wobec władz szkolnych i oświatowych a wrażliwością i krytycyzmem oraz koniecznością wyrażania własnych opinii w kwestiach nauczania i wychowania, ale także np. o problem podlegania ludziom niekiedy zupełnie niekompetentnym czy problem granic posłuszeństwa, lojalności. Nie rozwijając tego tematu, warto jedynie zaznaczyć, że chodzi tu o sprzeciw wobec instrumentalizacji nauczyciela przez władzę.

Źródłem wyzwań dla sumienia nauczyciela mogą być także relacje rzeczowe (np. gdy owoce jego pracy są marnotrawione albo wykorzystywane do niewłaściwych celów) oraz sytuacje, gdy trzeba wybierać między rozsądkiem a legalnością (np. kwestia tzw. nieżyciowych przepisów, sprzecznych ze zdrowym rozsądkiem, a niekiedy wprost ze sobą lub nawet wprost niemoralnych, których realizacja może przynosić szkodę ludziom lub całemu społeczeństwu). Rozwiązanie takich dylematów wydaje się pozornie proste: należy pójść za głosem sumienia i za zdrowym rozsądkiem. Trzeba jednak pamiętać o możliwych konsekwencjach. We wszystkich tych sytuacjach nauczyciel winien okazać się człowiekiem sumienia.

\section{Nauczyciel człowiekiem sumienia}

$\mathrm{Na}$ koniec warto sformułować kilka konkretnych zasad w odniesieniu do roli sumienia w życiu zawodowym nauczyciela. Przede wszystkim należy pamiętać, że istnieje tylko jedno sumienie i jedna moralność - zarówno na płaszczyźnie wiary, jak i pracy zawodowej. Sumienie jest szczególną dyspozycją człowieka i to każdego człowieka, a nie - jak się niekiedy to próbuje przedstawiać - tylko człowieka wierzącego. Jest ono zdolnością oceny swoich czynów; wyrazem naturalnej świadomości moralnej; najgłębszym wnętrzem człowieka; najtajniejszym ośrodkiem i sanktuarium, w którym rozpoznaje on głos Boga powołującego go do czynienia dobra ${ }^{19}$. Sumienie zatem jest miejscem spotkania i dialogu; dialogu nie tyle z prawem, z normą, ile

19 Por. Sobór Watykański II, Konstytucja duszpasterska o Kościele w świecie współczesnym Gaudium et spes, nr 16. 
z osobą - z Bogiem i z samym sobą; bezpośrednią i praktyczną normą moralności. W sumieniu człowiek dokonuje wyłącznie oceny moralnej swojego konkretnego czynu, wykonywanego tu i teraz. Tej oceny dokonuje w sposób rozumny w świetle obiektywnego prawa moralnego. Obiektywnego, tzn. nie tylko prawa Bożego objawionego, ale także prawa powszechnego, którego podstawowe normy są poznawalne bezpośrednio, w sposób spontaniczny jako złota reguła „dobro czyń, złego unikaj”. Tą regułą człowiek winien kierować się zawsze, a więc także w życiu zawodowym. Nie wolno zatem od człowieka żądać podwójnej moralności - jednej w relacji do Boga, a innej w pracy i życiu zawodowym.

Jak w każdej dziedzinie życia, także w pracy zawodowej, należy iść zawsze za głosem sumienia (constientia semper sequenda); dodajmy: za głosem sumienia prawdziwego, tzn. takiego, które dobro nazywa dobrem, a zło złem; takiego, które nie tworzy sobie norm na własny użytek, ale uznaje istnienie prawdy obiektywnej, której poszukuje i za którą pragnie iść. Jeśli więc człowiek rozpoznaje w normie moralnej prawdziwe kryterium dobra, czy też wprost nakaz Boży, winien jest uległość tej normie i winien podjąć zgodne z nią działanie. Człowiek winien jest także posłuszeństwo wobec prawa ludzkiego stanowionego (kościelnego, czy też świeckiego), o ile jest ono sprawiedliwie oraz stoi na straży prawdy i dobra. Natomiast może czuć się w sumieniu zwolnionym w konkretnym przypadku z zachowania prawa stanowionego ludzkiego, kiedy przekracza ono ramy racjonalności i tym bardziej kiedy jest ono niemoralne czy niesprawiedliwe ${ }^{20}$. Gdy np. przełożony nakazuje wykonanie rzeczy złej tzn. sprzecznej z wymogami porządku moralnego, z podstawowymi prawami osób lub wskazaniami Ewangelii, albo gdy próbuje narzucić określone poglądy (np. w kwestii edukacji seksualnej, poszanowania życia, małżeństwa i rodziny), człowiek nie jest zobowiązany w sumieniu do przestrzegania zarządzeń władz cywilnych.

Sumienie jest podstawowym wyznacznikiem ludzkiej godności. Na drodze sumienia człowiek odnajduje i nieustannie potwierdza swoją tożsamość. Poprzez sumienie odnajduje pełną prawdę o sobie i stara się żyć na miarę tej odkrytej prawdy. Jako akt rozumowego poznania prawdy przez osobę, nie pełni ono roli „narzędzia” samodzielnego określania, co jest dobre, a co złe, ale rolę świadka i pierwszego sędziego. Prawe sumienie, tzn. sumienie zdolne do odkrywania prawdziwej

$20 \quad$ Por. J. Wróbel, Sprzeciw sumienia z perspektywy moralnej, http://www.naszdziennik.pl/mysl/106045,sprzeciw-sumienia-z-perspektywy-moralnej.html (30.01.2015 r.). 
hierarchii wartości, jest najlepszym zabezpieczeniem ludzkiej wolności. Bywa bowiem też sumienie błędnie ukształtowane. Jednak nawet i wtedy nie wolno nikogo zmusić, aby postępował wbrew własnemu sumieniu.

Nie brakuje dzisiaj opinii, że praca, życie zawodowe (w tym praca nauczyciela) winny być pozbawione ocen moralnych - że winny być „odmoralnione”, etycznie zneutralizowane. Nie brakuje zabiegów, by człowiek przestał się troszczyć o dochodzenie do prawdy i dobra. Nie brakuje wreszcie prób przyznania sumieniu prerogatyw najwyższej instancji osądu moralnego; kategorycznego i nieomylnego decydowania o tym, co jest dobre, a co złe, a także prób zastąpienia sumienia prawem bądź autorytetem. Usiłuje się zepchnąć moralność na teren życia prywatnego. Dotyczy to zwłaszcza osób pełniących służbę społeczną. W imię pełnionej funkcji społecznej powinni oni rzekomo zrezygnować ze swojej osobistej moralności na rzecz moralności proponowanej przez państwo i społeczeństwo. Swoje przekonania moralne powinni pozostawić w domu, a w szkole (szpitalu czy urzędzie) kierować się wymaganiami sformułowanymi przez instytucje państwowe.

Wydaje się, że dzisiaj ludzie bez zasad moralnych i „bez sumienia” łatwiej mogą osiągnąć stanowiska, kosztem ludzi uczciwych. Dlatego współczesny człowiek często nie odczuwa już dylematów sumienia. Pochłonięty pasją zawodową, sam sprowadza się do roli przedmiotu; godząc się na zło sam pozwala, by jego sumienie było łamane. Sumienia bowiem nie można złamać bez jakiegoś współudziału tego, kogo sumienie jest łamane. Wierność sumieniu w życiu zawodowym może dziś oznaczać utratę pracy oraz inne konsekwencje. Dlatego prof. Chazan stracił stanowisko dyrektora szpitala Świętej Rodziny, aktor Marek Cichucki został zwolniony za to, że - powołując się na klauzulę sumienia - odmówił występu w spektaklu Golgota Picnic. Nie można wykluczyć, że kiedyś taką ofiarą stanie się dyrektor szkoły lub grupa nauczycieli, którzy posłużą się klauzulą.

Sumienie, klauzula sumienia obowiązuje w każdym zawodzie. Jeżeli człowiek ma dobrze uformowane sumienie, jeżeli kategoria dobra i zła funkcjonuje w nim poprawnie, to w pewnych sytuacjach musi powiedzieć „non possum”. Konsekwencje takiej wierności sumieniu są ogromne. Można stracić pracę, można zamknąć sobie drogę do awansu. Jeżeli jednak pójdzie się drogą konformizmu, to traci się to, co najbardziej cenne, czyli człowieczeństwo ${ }^{21}$. Jeśli zgodzimy się na ogra-

$21 \quad$ Por. P. Morciniec, Przeżywamy dyktature demokracji, http://www.fronda.pl/a/ ks-prof-piotr-morciniec-przezywamy-dyktature-demokracji-1,42990.html (30.01.2015 r.). 
niczenie sumienia nauczyciela, postawiamy go w sytuacji bezdusznego i bezmyślnego wykonawcy przepisów. Jest to fundamentalnie sprzeczne z sensem tego zawodu, który nie jest urzędnikiem, wypełniającym formularze zgodnie z jakimiś odgórnie narzuconymi schematami, ale jest osobą, w której ręku znajdują się losy drugiego człowieka.

Państwo, które uzurpuje sobie wtłaczanie na siłę przesłania edukacyjnego, swojego punktu widzenia, jest państwem totalitarnym. moralna To w państwie totalitarnym bowiem jednostka jest dla państwa i ma bezkrytycznie realizować jego wytyczne. Państwo demokratyczne natomiast istnieje ze względu na dobro poszczególnych ludzi. W państwie demokratycznym istnieje wolność sumienia, w totalitarnym natomiast wszyscy muszą się podporządkować oficjalnemu światopoglądowi. Ten oficjalny światopogląd reprezentują dzisiaj zwolennicy ideologii gender, seksedukatorzy, oraz ci, którzy pod hasłami równouprawnienia zacierają różnice między mężczyzną a kobietą, między miłością a seksem, między małżeństwem a luźnym związkiem, wzywając do odrzucenia „stereotypowych” ról przypisywanych płciom. Klauzula sumienia nauczyciela nie stanowi zagrożenia dla prawdy przekazywanej w szkole. Zagrożeniem są natomiast wszelkie próby łamania sumień, próby zastąpienia sumień przepisami i autorytetem władzy. Tym bardziej potrzebni są świadkowie wierności własnemu sumieniu; ludzie prawdziwie wolni, odważni, nie spętani konformizmem. Mamy takich wśród lekarzy, aktorów, prawników. Nie sposób nie ufać, że także wśród nauczycieli.

Słowa kluczowe: sumienie, klauzula sumienia, szkoła, etyka zawodowa.

\section{Bibliografia:}

1. Deklaracja wiary lekarzy katolickich i studentów medycyny w przedmiocie płciowości i płodności ludzkiej (5 marca 2014 r.), http://www.deklaracja-wiary.pl/img/dw-tresc.pdf (dostęp: 30.01 .2015 r.).

2. Deklaracja wiary nauczycieli? Hall: nie zatrudnia się ich w celu ewangelizacji uczniów, http://www.polskieradio.pl/5/3/Artykul/1190178,Deklaracja-wiary-nauczycieli-Hall-nie-zatrudnia-sie-ich-w-celu-ewangelizacji-uczniow (dostęp: 30.01 .2015 r.).

3. Klauzula sumienia $w$ szkotach? Nowicka: nauczyciel nie może cenzurować wiedzy, http://www.polskieradio.pl/9/299/Artykul/1195806, Klauzula-sumienia-w-szkolach-Nowicka-nauczyciel-nie-moze-cenzurowac-wiedzy (dostęp: 30.01.2015 r.).

4. Konstytucja Rzeczpospolitej Polskiej (2 kwietnia 1997 r.), Tekst ujednolicony: http://isap.sejm.gov.pl/DetailsServlet?id=WDU19970780483. 
5. Morciniec P., Przeżywamy dyktature demokracji, http://www.fronda.pl/a/ ks-prof-piotr-morciniec-przezywamy-dyktature-demokracji-1,42990.html (dostęp: 30.01.2015 r.).

6. Nauczyciele też będa podpisywać deklarację wiary? Minister: szkoła publiczna powinna być neutralna światopogladowo, http://www.polskieradio. pl/5/3/Artykul/1188918,Nauczyciele-tez-beda-podpisywac-deklaracje-wiary-Minister-szkola-publiczna-powinna-byc-neutralna-swiatopogladowo (dostęp: 30.01.2015 r.).

7. Sobór Watykański II, Konstytucja duszpasterska o Kościele w świecie współczesnym Gaudium et spes, [w:] Sobór Watykański II. Konstytucje. Dekrety. Deklaracje, Poznań 2002.

8. Stanisz P., Prawo do odmowy działania sprzecznego z sumieniem, www. przemyska.pl/plik/22141/ (dostęp: 30.01 .2015 r.).

9. Stanisz P., Sprzeciw sumienia a prawo państwowe, https://www.youtube. com/watch?v=E-HKn46VsOE (dostęp: 30.01 .2015 r.).

10. Staszewski W., Wierze, że uczę, http://polska.newsweek.pl/wierze-ze-ucze-o-klauzuli-sumienia-nauczycieli-newsweek-pl,artykuly,344944,1.html (dostęp: 30.01.2015 r.).

11. Trybulski Ł., Lekarze podpisuja klauzule sumienia, a co z reszta zawodów? Strażak, policjant, nauczyciel..., http://natemat.pl/104381,internauci-smieja-sie-z-klauzuli-sumienia-strazak-policjant-nauczyciel (dostęp: 30.01.2015 r.).

12. Wróbel J., Sprzeciw sumienia z perspektywy moralnej, http://www.naszdziennik.pl/mysl/106045,sprzeciw-sumienia-z-perspektywy-moralnej. html (dostęp: 30.01.2015 r.). 